\title{
Exports Trade and Economic Growth in Zanzibar
}

\author{
Salim Hamad Suleiman \\ Department of Planning, Policy and Research, \\ Ministry of Trade and Industry, Zanzibar \\ Suleiman Malik Faki \\ Department of Economics, \\ Zanzibar University, Zanzibar \\ Issa Moh'd Hemed \\ Department of Economics, \\ Zanzibar University, Zanzibar \\ Khamis Msellem Khamis \\ Department of Research and Consultancy, \\ Institute of Public Administration, Zanzibar
}

\begin{abstract}
We examined the applicability of the Export-Led Growth hypothesis for Zanzibar using annual time series data during the period of 1985-2016. The estimation results obtained from the cointegration test and Granger Causality test within the framework of a Vector Autoregressive (VAR) model supported the Export-Led Growth hypothesis for Zanzibar. Our results indicate that the hypothesis causes economic growth and the existing of long-run relationship between clove export trade and economic growth. In addition, analysis of Impulse Response Function (IRF) suggests that a sudden economic growth rate and an increase in clove export positively impact others with exception to labour. However, the sudden increase in share of clove export will cause adverse effect to economic growth rate.
\end{abstract}

Keywords: Clove Export, Economic Growth, VECM, Zanzibar

\section{INTRODUCTION}

Export trade is the key factor in promoting economic growth for both developing and developed countries. It is a vital source of foreign exchange that improves the balance of payments deficit and increases employment opportunities. Moreover, export trade facilitates the process of diffusion of technology from one country to another (Mohammed et al, 2012). The expansion of export trade has become the debated issue in the development, growth, and trade literature in both empirical and theoretical studies with a little consensus among the experts based on the framework of export-led growth hypothesis. Despite the tremendous studies, but still controversy exists on whether export trade stimulates economic growth of developing countries.

Empirically, some studies support positive impact of exports on economic growth by stimulating external demand for domestic products, and that result into increase in domestic production and efficient allocation of resources (Esfahani, 2001). Then, Yu (1998) asserts that export-expansion strategy is key factor in promoting economic growth of the nation while importation may impairment the domestic production which has negative effect to the overall economic performance. Similarly, Saleem and Sial (2015) argue that country should enforce export promotion strategies as a part of its appropriate development strategy to get 
sustainable economic growth. Moreover, Bernard and Jensen (1999) ascertained that export trade promotes economic growth pf the nation through reallocation of resources from their less efficient to more efficient productive activities. Hence, expansion of export trade play vital role in the economy by increasing total factor productivity (TFP) in developing countries.

Nonetheless, some studies found negative relationship between export trade and economic growth in developing countries.Abbas, 2012.The main reason given is that export trade tends to kill the domestic infant industries because these firms cannot compete with international producers in the world market. (Krugman and Venables, 1995; Rodrigues, 2010) suggested that the adoption of import substitution strategies to counter this problem. It is evident that previous studies provide mixed results on the empirical linkage between export trade and economic growth. indeed many studies have applied the different approach to study the relationship between exports and growth. In this study, we focus on clove exports to determine their potential role in stimulating economic growth of Zanzibar. This paper therefore, applies the Vector Autoregressive (VAR) approach to annual data from 1985 to 2016 to provide empirical evidence on the long run relationship between export and economic growth in Zanzibar.

The rest of the paper is organized as follows. Section two contains review on the export-growth literature; section three presents the econometric model and methodology; section four presents the empirical findings of the study; and section five presents the summary and conclusion.

\section{LITERATURE REVIEW}

Adam Smith and David Ricardo recognized the theoretical relationship between export trade and economic growth and the significant role an export trade plays in promoting economic growth. Smith and Ricardo suggested that export trade promote economic growth of the countries. Moreover, export trade generates foreign exchange earnings from exports enable a country to finance imports that are not available in the domestic economy. This relationship in the modern economics is called framework of export-led growth hypothesis. Supporters of export-led growth hypothesis assert that export trade is important growth engine because it increases the TFP of local firms resulted from increased economies of scale. They also argue that export trade plays crucial role in transfer of technology, improves managerial skills and skills of workers, and increases the productive capacity of domestic economy (see for example Rivera-Batiz and Romer, 1991; Grossman and Helpman, 1990).

A number of empirical studies support the export-led growth hypothesis. Most of these studies support the existence of positive association between exports and economic growth. Saleem and Sial (2015), examine the relationship between export and economic growth in Pakistan using annual time series data covered the period of 1973 to 2013. the study found the existence of positive contributions of real export on economic growth. Furthermore the study reveals the presence of bidirectional granger causality running from exports and economic growth both in the short run and long run. In addition to that, Raj and Chand (2017) estimate the relationship between exports and economic growth in Fiji employing the time series data between 2000 and 2015 . The results indicate the strong positive relationship between exports and economic growth. They further suggested that the government should give the subsidies to the agricultural sectors so as to improve domestic production and increases export and thereby revamp economic growth. Nguyen (2017) examined the impact of export on economic growth in Vietnam using the data covered the period of 15 years between 1990 and 2015. the study found the strong relationship between exports and economic growth in Vietnam. 
concluded that export as an engine to improve economics development through acceleration and modernization of industrial sectors in the economy.

Kingu (2013) investigated the responsiveness of clove export to Tanzanian economy before and after trade liberalization applying the econometrics and non parametric models between 1970 and 2010. The study revealed that cloves exports generate maximum earns in the long run when real exchange rate and world market price are take into consideration. Likewise Drama et al (2014) examined the important factors affect Zanzibar's clove export utilizing the ordinary Least Square (OLS) model for the time series data covers 25 years from 1980 to 2005 . The results of the study indicate that the price of exported products will accelerate the income to exporting countries. Moreover they further supported that the inclusive of human capital development will eventually enhance the economy of Zanzibar.

In addition to that Ucan (2016) examined the relationship between export and economic growth in Turkey. Using cointegration and granger causality techniques for the quarterly data covered the period between 2006 and 2015. The study concluded that in order to generate positive contribution of export to developing countries' economy, the human capital development and technological progress must take into consideration. Further add to that, Bakari (2017) employing annual time series data for the period between 1980 and 2015 to investigate the impact of exports on economics growth in Gabon implementing cointegration analysis and error correction model. The results reveal that the investment and export affect negatively on economic growth.

Yet, most of these studies have used the role of export trade which include all goods and services exported to abroad. This study uses clove export trade to evaluate its impact on economic growth in Zanzibar. Thus, it employs the VAR approach along IRF and variance decomposition techniques to test the robustness of the VECM and Granger causality results.

\section{Theoretical framework}

\section{METHODOLOGY}

As have been noted earlier, the objective of this paper is to investigate the empirical link between economic growth and export trade in Zanzibar. Previous empirical studies explained the concept of exports-growth relationship (Feder, 1982; Balassa, 1985; Ram, 1987; Lucas, 1988; Esfahani, 1991; Hutchison and Singh, 1992; Al-Yousif, 1997; Mohammed; 2012) analyzed the relation between export trade and economic growth by including exports into an augmented production function framework. Moreover, this study adopted a Feder model approach to provide evidence that export expansion acts as an engine of economic growth for Zanzibar. It is assumed in the model specification that economy consists of two sectors, export sector $(X)$ non-export sector $(N)$. Besides, human capital can work as a key factor of production and positively affects other factors of production. Hence, this study incorporates human capital as suggested by new growth theory together with capital and exports variables.

$$
Y=f(K, L A B, E X P)
$$

The above equation can be written in the econometric model and in their respective natural log form; The above model can be re-written as an econometric model for this study as following:-

$$
\ln Y_{t}={ }_{0}+{ }_{1} L K+{ }_{2} L L A B+{ }_{3} L E X P_{t}+
$$

Where $t$ is time, In indicates natural logarithm, $Y t$ is real GDP, $K t$ is gross fixed capital formation, LLABt is human capital, $X t$ is real exports of cloves, and et is error term. 
We used annual data covering the period from 1985 to 2016 to investigate the effect of export on economic growth in Zanzibar.Measures of all these variables are taken from Zanzibar Stating Trading Corporation (ZSTC) statistical database and Office of Chief Government Statistician (OCGS). The sample period under investigation begins from 1985 to 2016. Table 1 provides additional information on all variables.

Table1: Summary of Variables and Expected sign

\begin{tabular}{lllc}
\hline \multicolumn{1}{c}{ Variable } & \multicolumn{1}{c}{ Description } & Sources & $\begin{array}{c}\text { Expected } \\
\text { Sign }\end{array}$ \\
\hline Economic Growth & Real GDP & OCGS & \\
Human Capital (K) & Measured by Gross Capital Formation & OCGS & + \\
Human Capital (LAB) & Measured by number of labour force of country & OCGS & + \\
Export (EXP) & Measured by value of real clove export trade in & ZSTC & + \\
& US Dollar & & + \\
\hline
\end{tabular}

\section{Authors compilation}

\section{Empirical Methodology}

Through the use of econometric technique, our study examines clove export trade on economic growth in Zanzibar. It involve several steps to find out the relationship between love export trade on economic growth in Zanzibar as follows:-

\section{Unit Root Test}

In time series analysis, the first step is to test the stationarity of each series in determining the order of integration of all variables using Augmented Dickey-Fuller (ADF) test. In addition, the Dickey-Fuller (DF) is suitable, if the error term is not correlated and it becomes inapplicable if error terms are correlated. Time series which are not stationary means that have different mean at different points in time and their variance are not the same and increases with the sample size. Unit root test helps to avoid spurious regression. The ADF test is estimated by the following regression:

$$
Y_{t}=a_{0}+z t+a_{1} Y_{t} \quad 1++{ }_{i=1}^{p} a_{i} Y_{t} \quad 1+t
$$

where $\mathrm{a} 0$ is a constant, $\mathrm{t}$ is a deterministic trend, and enough lagged differences are included to ensure that the error term becomes white noise. If the autoregressive representation of Yt contains a unit root, the t-ratio for a1 should be consistent with the hypothesis a1=0.

\section{Johansen Cointegration}

The Johansen test was employed on stationary variables in order to determine the existence of long-run cointegration in the number of vectors that exist in is the system. To investigate the existence of a long run equilibrium relationship between exports and economic growth, we employed the maximum-likelihood test procedure established by Johansen and Juselius (1990) and Johansen (1991). Generally, Yt is a vector of $n$ stochastic variables, then there exists a k-lag vector autoregression with Gaussian errors of the following form:

$$
Y_{\mathrm{t}}=a+\quad 1 \quad Y_{t} \quad 1+\ldots+\quad k \quad 1 \quad Y_{\mathrm{t}} \quad k \quad 1+\quad Y_{t} \quad 1+z_{\mathrm{t}}
$$

where $\& 1, \ldots . . ., \& k-1$ and contains all deterministic elements. 


\section{Vector Error Correction Model (VECM) and Granger Causality Test}

Engle and Granger (1987) suggested that once variables were cointegrated, the error correction should be detected, at this stage the Error Correction Models (ECM) can be useful to find out the long run relationship with the VAR system. Moreover, ECM is useful since provide both short run and long run effects of variables. At this circumstance, the Error Correction Models (ECM) is used to test for both short run and long run causalities through lagged difference explanatory variables and through the lagged ECM term, respectively. From equation (1), the VECM model can be written as:

$$
\begin{aligned}
& L G D P 1 t=1 t \quad(L G D P \quad 0 \quad 1 L K \quad 2 L E X \quad 3 L L A B) t \quad 1+i_{i=1}^{j} 1, j L G D P 1 t \quad 1+ \\
& \underset{i=1}{j} 2, j \operatorname{LK} 1 t \quad 1+{ }_{i=1}^{j} 3, j \operatorname{LEX} 1 t \quad 1+{ }_{i=1}^{j} 4, j \operatorname{LLAB} 1 t \quad 1+1 t \\
& L K 2 t=2 t \quad\left(L G D P \quad 0 \quad 1 L K \quad 2 L E X \quad{ }_{i=1}^{j} L G D P 2 t \quad 1+\right. \\
& \underset{i=1}{j} \operatorname{LK} 2 t \quad 1+\prod_{i=1}^{j} \operatorname{LEX} 2 t \quad 1+i_{i=1}^{j} \operatorname{LLAB} 2 t \quad 1+2 t
\end{aligned}
$$

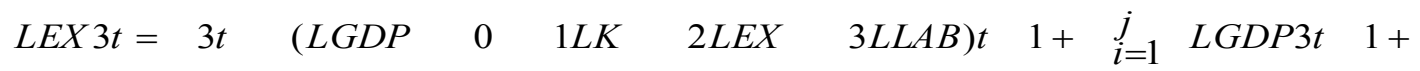

$$
\begin{aligned}
& i_{i=1}^{j} \operatorname{LK} 3 t \quad 1+j_{i=1}^{j} \operatorname{LEX} 3 t \quad 1+j_{i=1}^{j} \operatorname{LLAB} 3 t \quad 1+3 t \\
& L E X 4 t=4 t \quad(L G D P \quad 0 \quad 1 L K \quad 2 L E X \quad 3 L L A B) t \quad 1+j_{i=1}^{j} L G D P 4 t \quad 1+ \\
& { }_{i=1}^{j} L K 4 t \quad 1+{ }_{i=1}^{j} \operatorname{LEX} 4 t \quad 1+{ }_{i=1}^{j} \text { LLAB 4t } 1+4 t
\end{aligned}
$$

Therefore, we can run the VAR in levels and Granger non-causality on each variable block to determine relationship of the variables. Granger causality test can be presented as follows:

$$
\begin{aligned}
& C_{t}={ }_{i=1}^{n}{ }_{i} M_{t}{ }_{i}+{ }_{i=1}^{n}{ }_{i} C_{t}{ }_{i}+{ }_{1} E C T_{t}{ }_{1}+{ }_{1} \\
& I N T_{t}={ }_{i=1}^{n}{ }_{i} C_{t}{ }_{i+}{ }_{i=1}^{n} i N T_{t} i+{ }_{2} E C T_{t} \quad 1+2 t .
\end{aligned}
$$

Where ECTt-1 denotes the lagged residuals of the long-run relationship and The significance of the differenced explanatory variables indicates the short-run causality, whereas the significance of ECTt-1 confirms the long-run causal relationship.

\section{Impulse Response (IRF) and Variance Decomposition (VDC)}

We used IRF test in order to track the impact of shocks from economic growth to clove exports in Zanzibar and vice versa. On the other hand, application of variance decomposition method enabled us to see the extent to which changes in one variable are important in determining the changes in other variable.

\section{Unit Root Test}

\section{FINDINGS AND DISCUSSION}

The unit root tests results are presented in Table 2 below. The ADF test confirmed that all variables are non-stationary at level. However, after taking their first difference, the results show that the series became stationary. In other words, all series under the study, are integrated at order one, i.e. $I(1)$. 
Table 2: Unit Root Test

\begin{tabular}{|l|c|c|c|c|}
\hline \multicolumn{1}{|c|}{ Variable } & \multicolumn{2}{|c|}{ Level } & \multicolumn{2}{c|}{ First Difference } \\
\hline & $\begin{array}{c}\text { Constant } \\
\text { Without Trend }\end{array}$ & $\begin{array}{c}\text { Constant With } \\
\text { Trend }\end{array}$ & $\begin{array}{c}\text { Constant } \\
\text { Without Trend }\end{array}$ & $\begin{array}{c}\text { Constant } \\
\text { With Trend }\end{array}$ \\
\hline LGDP & -1.2207 & -1.5634 & -31.9087 & -32.7212 \\
& $(0.6453)$ & $(0.7826)$ & $(0.0001)^{* *}$ & $(0.0000)^{* *}$ \\
\hline LEX & -0.4876 & -2.396 & -7.44949 & -3.96653 \\
& $(0.8799)$ & $(0.3713)$ & $(0.0000)^{* *}$ & $\{0.0227\}^{*}$ \\
\hline LK & -1.651872 & -2.2313 & -3.01185 & -3.80472 \\
& $(0.4391)$ & $(0.4474)$ & $(0.0509)^{*}$ & $(0.0370)^{*}$ \\
\hline LLABOUR & 1.6863 & -2.8346 & -8.63204 & -4.09709 \\
& $(0.9991)$ & $(0.8390)$ & $(0.0000)^{* *}$ & $(0.0240)^{*}$ \\
\hline
\end{tabular}

Note: ${ }^{* *}$ and $*$ denotes significant at $1 \%$, and $5 \%$ significance level, respectively

\section{Johansen Cointegration Tests}

After detecting that all series are I(1), we applied Johansen test for co-integration to test the existence of long-run relationship among the non-stationary variables, which are presented in Table 3. The Johansen cointegration test results indicate the existence of at least one cointegrating vector at 5 percent significance level. The existence of cointegrating vector implies the presence of long-run relationship between economic growth and clove exports in Zanzibar. These results coincide with results of Keho, (2017); and Ndubuisi (2012) who attested that exports can play a greater role in enhancing economic growth. The export of cloves is a vital source of foreign exchange, improves the balance of payments deficit and increases employment opportunities as well (Mohamed et al, 2012).

Table 3: Johansen Cointegration Tests

\begin{tabular}{|c|c|c|c|c|c|c|}
\hline Hypothesized & Trace & Max-Eigen & \multicolumn{2}{|c|}{ Critical Values (5\%) } & \multicolumn{2}{|c|}{ Probability (5\%) } \\
\hline No. of CE(s) & Statistic & Statistic & Trace & Max-Eigen & Trace & Max-Eigen \\
\hline $\mathrm{r}=0$ & $69.16613^{* * *}$ & $36.48826^{* * *}$ & 47.85613 & 27.58434 & 0.0002 & 0.0028 \\
\hline $\mathrm{r} \leq 1$ & $32.67788^{* *}$ & 18.32039 & 29.79707 & 21.13162 & 0.0227 & 0.1183 \\
\hline $\mathrm{r} \leq 2$ & 14.35749 & 11.46079 & 15.49471 & 14.26460 & 0.0736 & 0.1326 \\
\hline $\mathrm{r} \leq 3$ & 2.896697 & 2.896697 & 3.841466 & 3.841466 & 0.0888 & 0.0888 \\
\hline
\end{tabular}

Note: ${ }^{* *}$ denotes significant at $5 \%$ significance levels.

\section{VECM and Granger Causality results}

The results of the long run estimates from VECM indicated that both capital and exports contribute positively to economic growth, capital having the larger impact. However, labour contributed negatively to economic growth. Furthermore, a 1 percent increase in clove exports leads to 0.79 percent increase in real GDP in the long run. This finding provides empirical support for the export-led growth hypothesis that is expansion of export activities leads to higher level of GDP.

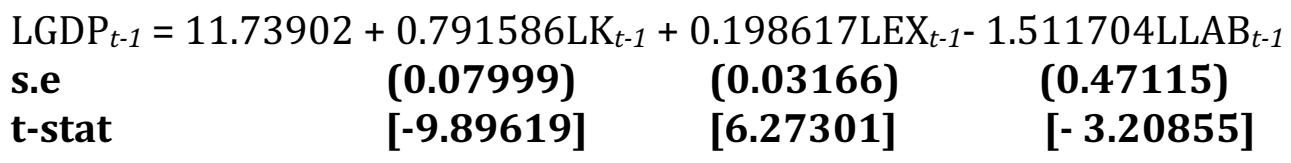


As mentioned earlier, the positive relationship between exports and GDP was expected because export is part of total GDP. The results which are presented in Table 4 indicate that variables are cointegrated, and therefore are causally related. Meanwhile, estimates of the error correction terms show that exports Granger-cause economic growth in the long run. In addition, both capital and labour Granger cause economic growth in the long run. With respect to the short-run causality, there is no evidence of causality of export and labour to economic growth when total GDP is considered. On the contrary, economic causes growth capital in the short run. These findings indicate that the export-led growth hypothesis for Zanzibar is a longrun phenomenon, thus, the clove export trade Granger results to economic growth during the period of study.

Table 4: Granger Causality Results based on VECM

\begin{tabular}{|c|c|c|c|c|c|}
\hline & \multicolumn{4}{|c|}{ Independent Variables } & \multirow{2}{*}{$\begin{array}{c}\text { ECT }_{t-1} \\
\text { coefficient }\end{array}$} \\
\hline Dependent & \multicolumn{4}{|c|}{$\begin{array}{c}{ }^{2} \text {-statistics of lagged } 1^{\text {st }} \text { differenced term } \\
{[p \text {-value] }}\end{array}$} & \\
\hline Variable & $\Delta$ LGDP & $\Delta \mathbf{L K}$ & $\Delta$ LEX & $\Delta$ LLAB & (t-ratio) \\
\hline$\Delta$ LGDP & -- & $\begin{array}{c}0.42 \\
{[0.519]}\end{array}$ & $\begin{array}{c}0.045 \\
{[0.8249]}\end{array}$ & $\begin{array}{c}1.032 \\
{[0.3097]}\end{array}$ & $\begin{array}{c}-0.069689^{* *} \\
{[-1.84238]}\end{array}$ \\
\hline$\Delta \mathbf{L K}$ & $\begin{array}{c}6.14^{* *} \\
{[0.013]}\end{array}$ & -- & $\begin{array}{c}0.06 \\
{[0.8022]}\end{array}$ & $\begin{array}{c}0.43 \\
{[0.5102]}\end{array}$ & $\begin{array}{c}4.120926^{* *} \\
{[4.42676]}\end{array}$ \\
\hline$\Delta \mathrm{LEX}$ & $\begin{array}{c}0.00 \\
{[0.9479]}\end{array}$ & $\begin{array}{c}4.21^{* *} \\
{[0.0402]}\end{array}$ & -- & $\begin{array}{c}0.01 \\
{[0.9301]}\end{array}$ & $\begin{array}{l}-0.012066 \\
{[-0.10752]}\end{array}$ \\
\hline$\triangle$ LLLABOUR & $\begin{array}{c}0.001 \\
{[0.9304]}\end{array}$ & $\begin{array}{c}0.46 \\
{[0.4994]}\end{array}$ & $\begin{array}{c}0.02 \\
{[0.8975]}\end{array}$ & -- & $\begin{array}{c}-0.067443 \\
{[-1.20398]}\end{array}$ \\
\hline
\end{tabular}

Note: ${ }^{* * *}$ and ${ }^{* *}$ denotes significant at $1 \%$ and $5 \%$ significance levels, respectively.

\section{Impulse Response (IRF) and Variance Decomposition (VDC) Impulse Response (IRF)}

The study used the IRF analysis to provide empirical analysis of economic growth and clove exports in the VAR system to one standard deviation of shock, as presented in Figure 1 . The finding shows that a positive shock in economic growth causes a positive response to clove export. However, the export tend to decline in the following years (year two to year four) before it stabilizes in subsequent years; thus, a sudden economic growth have a positive effect to others except labour. On the other hand, positive shocks in clove exports have positive and significant impact on economic growth, though however, impact is drastically reduced to negative in next period (year two). Moreover, in the following period (year three) the economic growth rejuvenated positively but not maintained. For instance, from third period (i.e. year three) to ninth period, the Zanzibar economy witnessed a significant negative effect of the shocks. These results suggest that the sudden increase in share of clove export cause an adverse effect to the economic growth rate.

\section{Variance Decomposition (VDC)}

The study employed the variance decomposition in forecasting and investigating the dynamic relationship between export and economic growth for the case of Zanzibar. Similarly, 10 years interval is used to provide a literal breakdown of the change in the value of the variable in a given period arising from a change in the same variable in addition to another variable in the previous period. Table 5 and 6 provide results of variance decomposition analysis for both economic growth and exports, respectively. We found that its economic growth own shock which explain 100 percent in the first period, and the percentages are still significant over the forecast period. Furthermore, export has slight contribution on economic growth compared to 
capital and labour. However, export variance is relatively greater in the short run than it is in the long run. In contrast, both capital and labour variances are increased from 0.736 percent and 0.714 percent in the second period reaching to 3.074 percent and 6.794 percent in the tenth year respectively. We also found that change in real GDP has short run influence on export which is explained by the innovative shock of 15.69 percent and reached 4.922 percent in the tenth year. Interesting, there is significant influence from capital and labour in the short and long run with 23.90 percent and 33.36 percent respectively.

Table5: Variance Decomposition of LGDP

\begin{tabular}{|l|c|c|c|c|c|}
\hline \multicolumn{6}{|l|}{ Variance Decomposition of LGDP: } \\
\hline Period & S.E. & LGDP & LEX & LK & LLAB \\
\hline 1 & 0.068627 & 100.0000 & 0.000000 & 0.000000 & 0.000000 \\
\hline 2 & 0.108007 & 95.36353 & 3.186319 & 0.736282 & 0.713864 \\
\hline 3 & 0.139730 & 93.40227 & 2.694220 & 1.175099 & 2.728408 \\
\hline 4 & 0.167072 & 92.14598 & 2.194658 & 1.844944 & 3.814423 \\
\hline 5 & 0.192076 & 91.05931 & 1.904736 & 2.293835 & 4.742119 \\
\hline 6 & 0.214555 & 90.35652 & 1.693805 & 2.547382 & 5.402295 \\
\hline 7 & 0.235166 & 89.82471 & 1.531366 & 2.744751 & 5.899177 \\
\hline 8 & 0.254186 & 89.42681 & 1.413124 & 2.886685 & 6.273378 \\
\hline 9 & 0.271931 & 89.12150 & 1.320937 & 2.991971 & 6.565591 \\
\hline 10 & 0.288597 & 88.88262 & 1.248309 & 3.074336 & 6.794734 \\
\hline
\end{tabular}

Table 6: Variance Decomposition of LEX

\begin{tabular}{|l|c|c|c|c|c|}
\hline \multicolumn{5}{|l|}{ Variance Decomposition of LEX: } \\
\hline Period & S.E. & LGDP & LEX & LK & LLAB \\
\hline 1 & 1.688952 & 15.69194 & 84.30806 & 0.000000 & 0.000000 \\
\hline 2 & 1.900753 & 12.39190 & 71.23547 & 8.312872 & 8.059755 \\
\hline 3 & 2.014163 & 11.07714 & 65.91388 & 9.041844 & 13.96713 \\
\hline 4 & 2.239341 & 9.055017 & 59.01042 & 12.97790 & 18.95666 \\
\hline 5 & 2.434732 & 7.769870 & 53.07125 & 16.56117 & 22.59771 \\
\hline 6 & 2.634526 & 6.865783 & 48.33129 & 18.74533 & 26.05760 \\
\hline 7 & 2.824513 & 6.181137 & 44.80153 & 20.54796 & 28.46938 \\
\hline 8 & 3.008717 & 5.659849 & 41.91799 & 21.95370 & 30.46847 \\
\hline 9 & 3.182400 & 5.251451 & 39.65928 & 23.02966 & 32.05961 \\
\hline 10 & 3.348822 & 4.922650 & 37.82039 & 23.90084 & 33.35612 \\
\hline
\end{tabular}

\section{CONCLUSION}

The study employed the VECM approach to the annual data covering the period of 1985 to 2016 toe examine the impact of export trade on economic growth in Zanzibar. Furthermore, IRF technique was purposefully applied to examine the manner through which the shock in one variable affects the others in both models. In addition, we performed the variance decomposition analysis to examine the impact of magnitude of shock in one variable on other variable. Findings indicate an existing long-run relationship between clove export trade and economic growth and support the export-led growth hypothesis that exports causes economic growth for the case of Zanzibar. In addition, the IRF analysis suggests that a sudden economic growth rate contributes to the positive effect to others except labour, and in contrast, a sudden increase in share of clove export affects economic growth rate. Conclusively, this may be the cause of low level of capital formation and development of capital; which fail to support the higher economic growth rate or higher export share. We, therefore share our views that Zanzibar could put more emphasis on increasing capital accumulation and invest in development of human capital. 


\section{Reference}

Abbas, S. (2012), Causality between exports and economic growth: Investigating suitable trade policy for Pakistan. Eurasian Journal of Business and Economics, Volume 5(10), pp. 91-98.

Al-Yousif, Y. K. (1997), Exports and economic growth: Some empirical evidence from the Arab Gulf countries. Applied Economics, Volume 29(6), pp. 693-697. http://dx.doi.org/10.1080/000368497326624

Athar Iqbal (2012), "Relationship between Exports and Economic growth of Pakistan" European Journal of Social Sciences, ISSN 1450-2267 Vol.32 No.3 (2012). Pp. 453-460.

Bakari S (2017), "The long Run and Short Run Impact of Exports on Economic Growth: Evidence from Gabon", Department of Economics, University of Tunisia, Tunisia.

Bernard, A.B., \& Jensen, J.B. (1999). Exporting and Productivity. NBER Working Paper, No. 7135.

Esfahani, H. S. (1991), Exports, imports, and economic growth in semiindustrialized countries. Journal of Development Economics, Volume 35(1), pp. 93-116. http://dx.doi.org/10.1016/0304-3878(91)90068-7

Esfahani, Hadi Salehi (2001). Exports, imports, and economic growth in semi-industrialized countries, Journal of Development Economics, (35) 93-116

Ewetan and Okecodua (ND), "Econometric Analysis of exports and economic growth in Nigeria", Department of Economics and Development Studies Covenant University, 10 Idiroko Road Ota, Ogun State, Nigeria

Feder, G. (1982), On exports and economic growth. Journal of Development Economics, Volume 12(1-2), pp. 5973. http://dx.doi.org/10.1016/0304-3878(83)90031-7

Grossman, G.M., \& E. Helpman (1990). Comparative Advantage and Long Run Growth. American Economic Review, 80, 796-815.

Hutchison, M. and N. Singh (1992), Exports, non-exports and externalities: A Granger causality approach. International Economic Journal, Volume 6(2), pp. 79-94. http://dx.doi.org/10.1080/10168739200000013

Keho, Y (2017), The exports and economic growth nexus in cote d'ivoire: evidence from a multivariate time series analysis, Asian Journal of Economic Modelling, DOI: 10.18488/journal.8/2017.5.2/8.2.135.146

Kingu J (2013), "Cloves Export response to trade liberalization in Tanzania: A cointegration Analysis", Journal of Economics and sustainable Development, ISSN 2222-1700 (paper) ISSN 2222-2855 (Online) Vol.5, No.1, 2014.

Krugman, Paul R., \& Anthony J. Venables. (1995). Globalization and the inequality of nations. Quarterly Journal of Economics, CX, 857-880

Lucas, Robert E. (1988), On the mechanic of economic development. Journal of Monetary Economics, Volume 22(1), pp. 3-42. http://dx.doi.org/10.1016/0304-3932(88)90168-7

Nguyen (2016), "Impact of Export on Economic Growth in Vietnam: Empirical Research and Recommendations" International Business and Management, Vol. 13, No. 3, 2016,pp. 45-52, Canada.

Owusu EL (2018), "Primary Commodity Export and Economic Growth Nexus: The Case of Ghana" research Journal of Economics 2:1

Raj and Chand (2017), "Analysis of Fiji's Export and its Impact on Economic Growth" International journal of business and social research, Volume 07, issue 03, 2017.

Ram, R. (1987), Exports and economic growth in developing countries: Evidence from time-series and crosssection data. Economic Development and Cultural Change, Volume 36(1), pp. 51-72.

http://www.jstor.org/stable/1153992

Rivera-Batiz, L.A., \& P.M. Romer (1991). Economic Integration and Endogenous Growth. Quarterly Journal of Economics, 206, 531-555.

Rodrigues, Mauro (2010). Import Substitution and Economic Growth. Journal of Monetary Economics, Vol. 57, No. 2,2010

Saleem Adeel and Sial Maqbool (2015), "Exports-growth nexus in Pakistan, Contegration and Causality Analysis", Pakistan Economic and Social Review volume 53, No. 1 (summer 2015), pp. 17-46.

Shoka I (2015, "contribution of Agriculture to the Economic growth in Zanzibar" research report, Mzumbe University, Tanzania

Ucan $O$ (2016), "The relationship between Export and Economic Growth in Turkey" European journal of scientific research. Retrieved https://www.researchgate.net/publication/314235136 
Yu, Qiao (1998). Capital investment, international trade and economic growth in China: Evidence in the 1980-90s, China Economic Review, 9 (1), 73-84.

\section{APPENDIX FIG.1: IMPULSE RESPONSE FUNCTION}

Response to Cholesky One S.D. Innovations

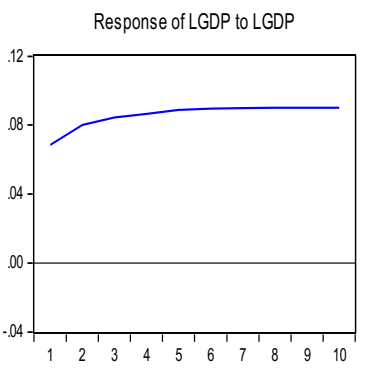

Response of LGDP to LEX

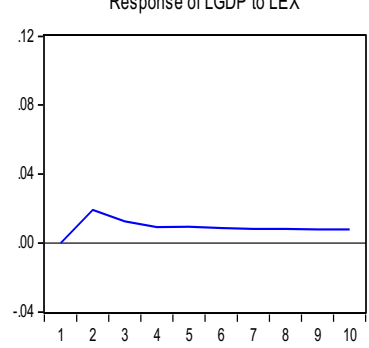

Response of LEX to LEX

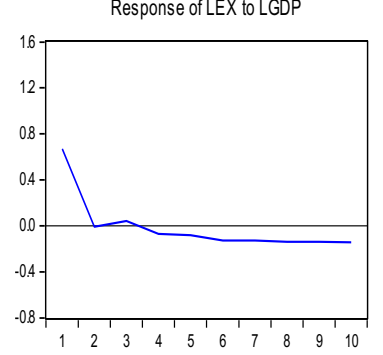

Response of LK to LGDP

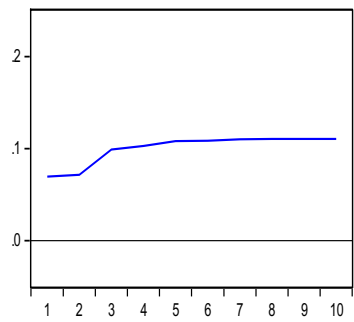

Response of LLABOUR to LGDP
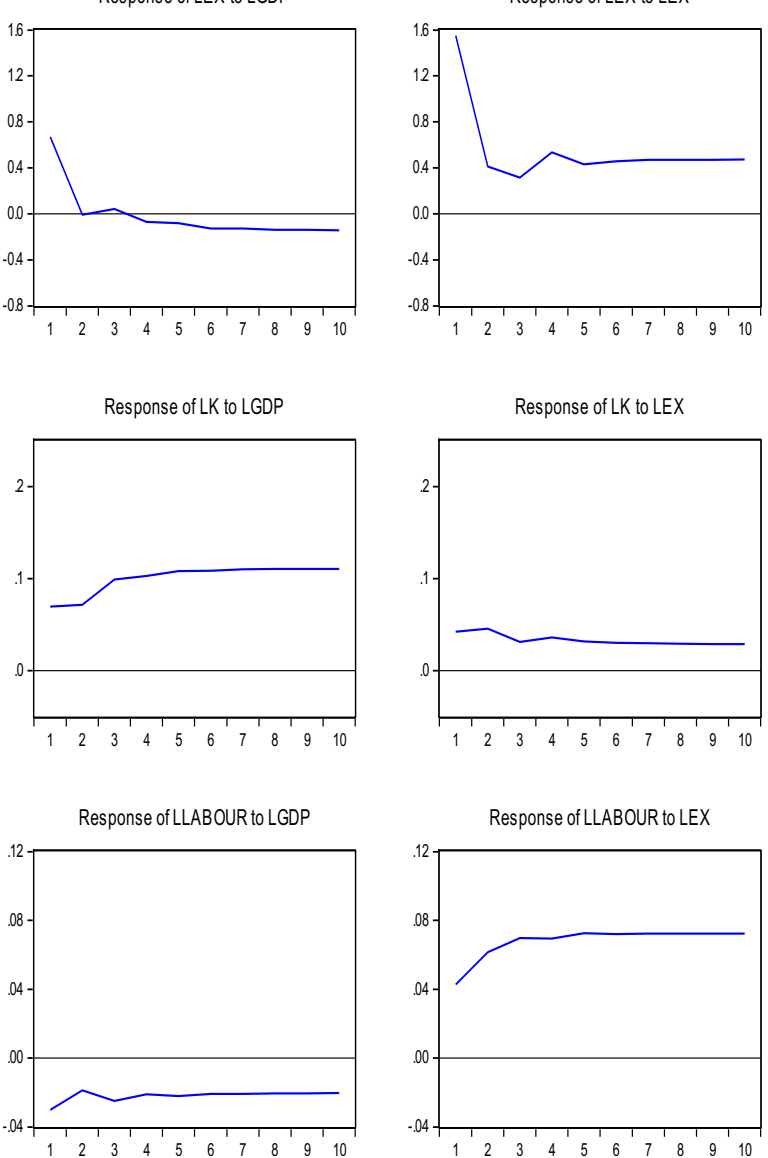

Response of LK to LEX

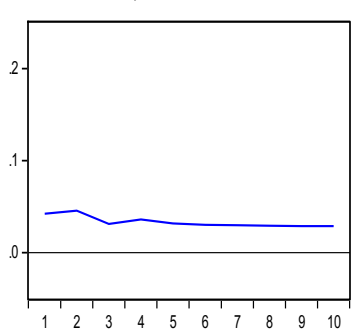

Response of LLABOUR to LEX

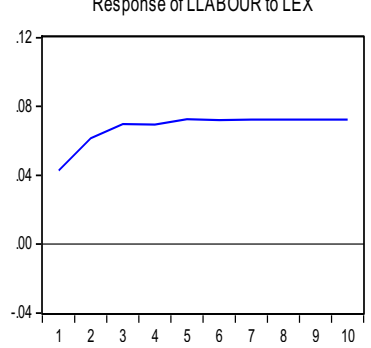

Response of LGDP to LK

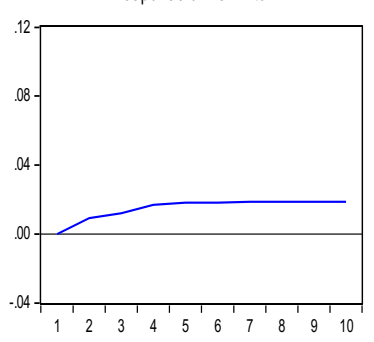

Response of LEX to LK

Response of LGDP to LLABOUR
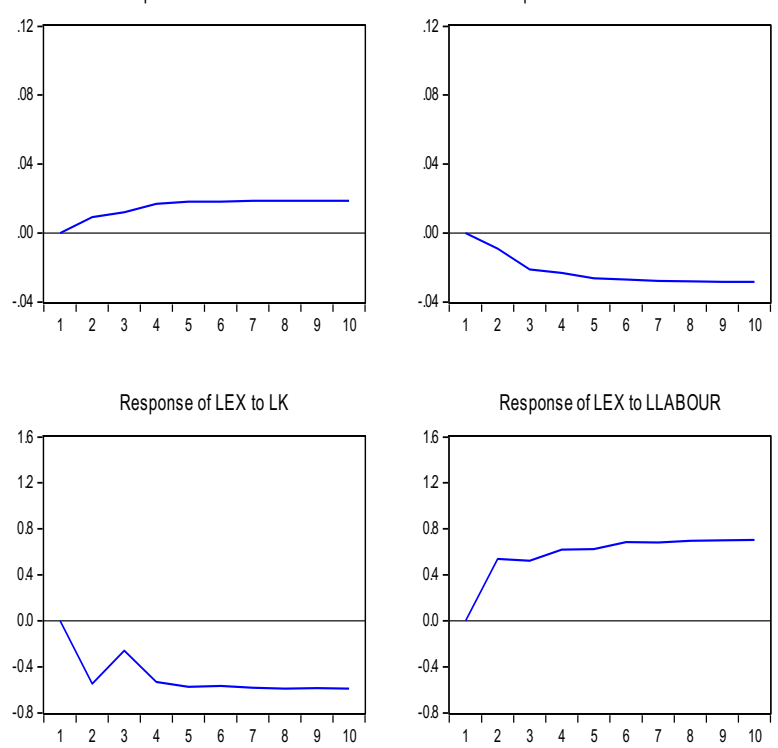

Response of LK to LK

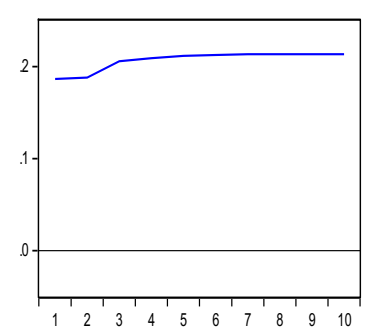

Response of LLABOUR to LK

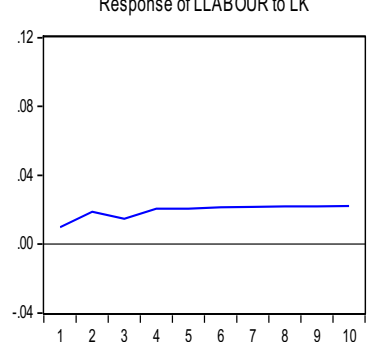

Response of LEX to LLABOUR

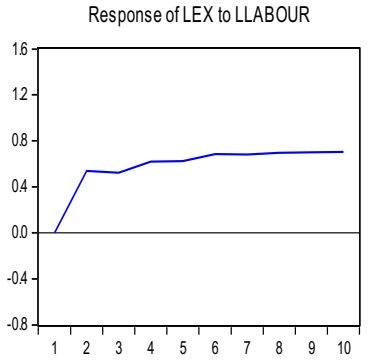

Response of LK to LLABOUR

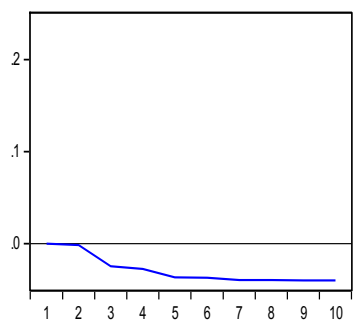

Response of LLABOUR to LLABOUR

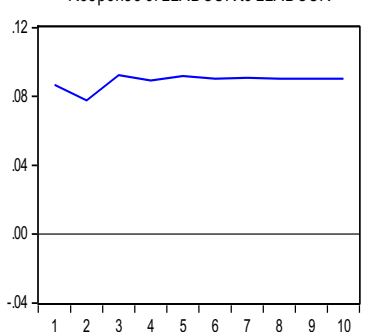

